\title{
Carbon Fiber Composites Application and Recycling in Kazakhstan and Neighboring Countries
}

\author{
Arshyn MEIIRBEKOV ${ }^{\mathrm{a}}$, Akniyet AMANTAYEVA ${ }^{\mathrm{a}}$, Serik TOKBOLAT ${ }^{\mathrm{b}}$, Aidar \\ SULEIMEN $^{\text {a }}$, Shoaib SARFRAZ ${ }^{\mathrm{c}}$, and Essam SHEHAB ${ }^{\mathrm{a}, 1}$ \\ a Mechanical and Aerospace Engineering Department, School of Engineering and \\ Digital Sciences, Nazarbayev University, Nur-Sultan, Kazakhstan \\ ${ }^{\mathrm{b}}$ School of Architecture, Design and the Built Environment, Nottingham Trent \\ University, Nottingham NG1 4FQ, UK \\ ${ }^{c}$ Manufacturing Department, School of Aerospace, Transport and Manufacturing, \\ Cranfield University, Cranfield, Bedfordshire, MK 43 OAL, UK
}

\begin{abstract}
The use of carbon fiber reinforced polymers (CFRPs) has expanded in many industries due to superior properties compared to traditional materials. Nevertheless, their recycling is challenged by immature recycling market and poor legislative support. This study evaluates the application and disposal of CFRPs within the different industries in Kazakhstan. The study adopted a market-based analysis approach to understand the up-to-date levels of application of CFRPs across manufacturing, construction, aviation, and other relevant industries of Kazakhstan. The study also considered CFRP markets and associated recycling practices in neighboring countries such as China and Russia which have a significant impact on Kazakhstan in terms of import and export of materials and waste. The research findings indicate that the application of CFRPs varies among industries, construction being the most prominent, however, their recycling is not as organized as in other waste types such as plastic, metals, etc. Russia and China will be generating thousands of tonnes of CFRP waste originating from the wind turbine and aviation sectors in future, from which Kazakhstan may also see some benefits. The findings of the study are deemed to be useful for the government of Kazakhstan and waste recycling associated stakeholders for future considerations.
\end{abstract}

Keywords. CFRP, recycling, Kazakhstan, Carbon Fiber Composites

\section{Introduction}

Carbon fiber reinforced polymer (CFRP) is an increasingly popular material in various industries ranging from aerospace engineering to wind turbine blades and sports equipment manufacturing. The main advantages of this material over other alternatives are superior mechanical resistance, higher stiffness, and lighter weight $[1,2]$. The need for lightweight material, for example, in the automotive and aviation industries, as well as the urgent need for decreasing $\mathrm{CO}_{2}$ emissions, can also be considered as drivers for CFRP-related market development. These advantages and drivers could be among the

${ }^{1}$ Corresponding Author, Mail: essam.shehab@nu.edu.kz. 
reasons boosting the global demand for CFRPs which is rapidly increasing and is expected to reach up to 200 kilotons by 2022, while the global revenue of CFRP is going to grow from $\$ 17.1$ billion in 2020 to more than $\$ 31.5$ billion by 2025 [3]. The downside of this trend is the major environmental challenges resulting from composite materials manufacturing (up to $40 \%$ becomes waste during manufacturing CRFP which is predicted to translate into 31000 metric tons of waste in 2021) and end-of-life (EOL) products $[4,5]$. Currently, only a few countries have carbon fiber recycling plants at an industrial scale (see Table 1). Moreover, most of the recycling plants tend to be located far from the waste collection and production locations which makes transportation costly and challenging. Overall, the carbon fiber composite materials recycling market is underdeveloped due to challenges, for example, with the supply chain. As a result, a great proportion of the CFRP waste ends up in landfills or sent for incineration, which are not complying with legislations and sustainability [6].

Table 1. Current CFRP recycling companies with a capacity of more than 1000 metric tons/year.

\begin{tabular}{|c|c|c|c|c|}
\hline Recycling company & $\begin{array}{l}\text { Recycling } \\
\text { Technology }\end{array}$ & $\begin{array}{l}\text { Capacity } \\
\text { (ton/year) }\end{array}$ & Website & Sources \\
\hline $\begin{array}{l}\text { Carbon Conversions } \\
\text { (USA) }\end{array}$ & Pyrolysis & 1800 & https://carbonconversions.com/ & {$[7]$} \\
\hline $\begin{array}{l}\text { CFK Valley Stade } \\
\text { Recycling GmbH \& } \\
\text { Co KG (Germany) }\end{array}$ & Pyrolysis & 1000 & https://www.cfk-recycling.de/ & {$[8]$} \\
\hline $\begin{array}{l}\text { ELG Carbon Fibre } \\
\text { (UK) }\end{array}$ & Pyrolysis & 1700 & https://www.elgcf.com/ & [9] \\
\hline Karborek RCF (Italy) & Pyrolysis & 1500 & http://www.karborekrcf.it/ & {$[10]$} \\
\hline $\begin{array}{l}\text { SGL Automotive } \\
\text { Carbon Fibres US } \\
\text { site }\end{array}$ & $\begin{array}{l}\text { Pyrolysis, uses } \\
\text { released gas as an } \\
\text { energy source }\end{array}$ & 1500 & https://www.sglcarbon.com/ & {$[6]$} \\
\hline $\begin{array}{l}\text { Toray Industries } \\
\text { (Japan) }\end{array}$ & Pyrolysis & 1000 & https://www.toray.com/ & {$[6]$} \\
\hline
\end{tabular}

Another potential reason for the underdevelopment of composite waste management could be linked to poor legislative support and targeted regulations for composite materials disposal. For example, in the EU, there are only requirements for the amount of CFRP material that needs to be recovered or recycled from EOL vehicles according to the 2000/53/EC EU Directive stipulated. According to Delvere et al. [11], the amount of CFRP waste will reach 165000 metric tons in the USA and 145000 metric tons in Europe by 2050 .

The industry range where CFRP is used is widening. For example, the demand for carbon fiber in the aerospace industry reached 26000 metric tons in 2020 due to the increased application of the material in commercial aircraft manufacturing such as Boeing 787 and Airbus A350 models [4]. Moreover, the sports inventory industry is actively applying CFRP in the production of sports equipment such as bicycles by creating an estimated demand for CFRP of 15 kilotons in 2020 [4]. Lastly, there is a growing trend in using CFRP in wind turbine blade manufacturing because the material allows making huge blades with less cost and weight.

This research aims to explore the current status of application of the composite materials in Kazakhstan and evaluate their recycling opportunities. The market of neighboring countries such as Russia and China were also considered in a comparative 
analysis due to their potential and volume of use of CFRPs. It was also important to consider these countries due to the high volume of import and export of materials and waste in and out of Kazakhstan. For this purpose, the markets of carbon fibers within Kazakhstan and neighboring countries were analyzed to reflect current levels of utilization across industries by bringing a transdisciplinary approach to the problem. Exploration of the current recycling state of composite recycling in the region requires not only a deep understanding of recycling techniques and economic aspects but also the linking of these concepts through a real-world context.

To achieve the aim, among others, the wind turbine and aerospace industry were analyzed in order to determine the potential CFRP waste volumes. Besides, the local market of carbon fiber products was analyzed to determine the main players and current development levels. It is important to mention that the data on carbon fiber materials supply and use balance was provided by the Bureau of National Statistics of the Republic of Kazakhstan.

\section{Application of CFRP and recycling associated waste in Kazakhstan and neighboring countries}

Kazakhstan and its neighboring countries such as Russia and China are reported to be associated with CFRP waste. This section investigates the industries where CFRP is used the most and attempts to evaluate the potential waste available in these countries.

\subsection{Kazakhstan}

In order to assess the impact of recycling carbon fiber waste in Kazakhstan, it was necessary to estimate the potential volume of CFRP waste originating from commercial aviation and wind power sectors, as the overwhelming majority of CFRP is used in mentioned industries ( $36 \%$ and $13 \%$ of global demand corresponded to aviation and wind turbine sectors respectively in 2020) [12]. However, based on the research findings it can be stated that air fleet size and wind turbine numbers in Kazakhstan are not increasing at the pace which would make recycling issues critical. The size of the fleet employed by the main commercial airlines does not exceed 100 planes which are mainly leased from foreign counterparts for specific time periods [13]. This implies that the airplanes are returned after the end of the lease term which means that the waste does not stay in Kazakhstan.

In terms of the wind turbines sector, currently there are 22 wind turbine stations operating in Kazakhstan with a total capacity of 404 MW energy generation whereas the total renewable energy capacity (including solar panels and hydroelectric power stations) is $1500 \mathrm{MW}$ [14]. Assuming that $1 \mathrm{~kW}$ capacity requires $10 \mathrm{~kg}$ of rotor blade $(6 \%$ of which CFRP), the potential CFRP waste from the current installed wind turbines is estimated to be 242 tons [12]. However, $45 \%$ of all the renewable energy generated in Kazakhstan during 2020 was linked to wind turbines which shows the potential of this type of energy in the country [15]. Also, the Kazakhstani government is planning to increase the share of renewable energy power up to $10 \%$ and $50 \%$ in 2030 and 2050 , respectively [16]. Based on these facts, it can be stated that the wind turbine sector of Kazakhstan might generate thousands of tons of CFRP waste in a foreseeable future and cause issues if not recycled or disposed sustainably. 
According to the Bureau of National Statistics [17], carbon fiber products in a form of prepregs, mats, and laminates are not in great demand, though the usage of carbon fiber reinforced composites is becoming more popular. The application of carbon fibers varies among industries, construction being prominent. CFRP products are widely used for reinforcements in load-bearing structures such as columns and beams. Figure 1 represents the levels of carbon fiber utilization in Kazakhstan, which was extracted from the commodity nomenclature "carbon fibers and products from them" [17]. It is evident from Figure 1 that the total volume of CFRP used in Kazakhstan is increasing every year. However, it is noted that during the year of 2020 import levels of carbon fiber products to Kazakhstan have decreased due to the COVID-19 pandemic.

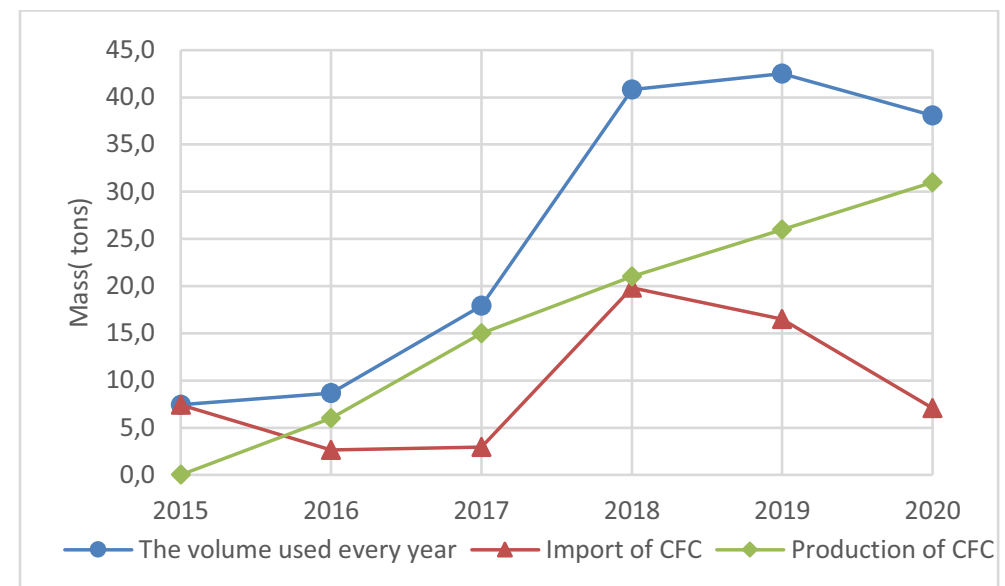

Figure 1. Carbon fiber materials' turnover in Kazakhstan between 2015-2020.

As was expected, the import and export volumes of carbon fiber materials are extremely small in comparison to the export and import rates of cheaper composite material - glass fiber products as illustrated in Figure 2. This is because glass fibers are cheaper and extensively used in a range of industries such as automotive, construction, energy sector, etc. [18]

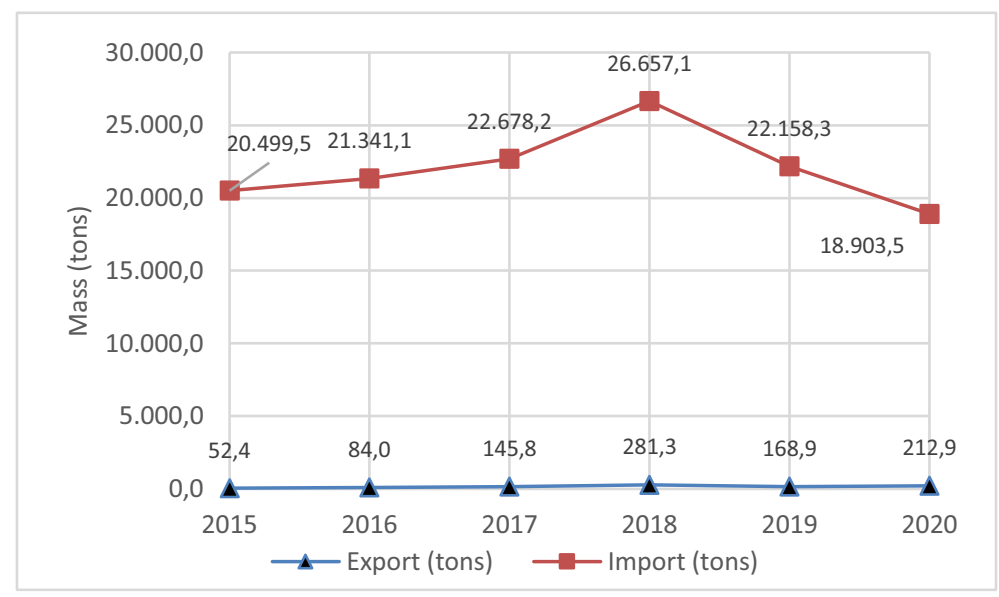

Figure 2. Import and Export of Glass Fiber Materials in Kazakhstan 2015-2020. 
The recycling of CFRP in Kazakhstan is not as organized as in other waste types such as plastic, metals, etc. Although there is a wide-scale supply of CFRPs to the market, there is no comprehensive system in place which would allow the same scale recycling.

\subsection{Players in Carbon Fiber Market in Kazakhstan.}

It is clear from the previous section that the application of carbon fiber in Kazakhstan is limited in terms of total volumes, though there are several companies that are involved in manufacturing or retailing carbon fiber products. For example, a company called "Kaztechnoinnovations" deals with the manufacturing of composite parts up to $6 \mathrm{~m}$ in length using the methods of molding, vacuum bagging, and pultrusion [19]. There is another worth-mentioning company "Most\&K" (the official representative of “Compozit” LLC Russia, partner of UMATEX) which strengthens structural parts of old buildings, industrial facilities, and bridges using carbon fiber composites. The company had prior success in strengthening reinforced concrete structures of a shopping mall and a 24-story building in two cities using carbon fiber tapes and lamels in Kazakhstan [20]. The company also promotes chopped and milled carbon fiber as a filler for application in concrete structures. The other companies are only involved in the retail and wholesale of carbon fiber products mostly produced in Russia and China. The list of mentioned companies is provided in Table 2.

Table 2. Companies in Kazakhstan selling carbon fiber products.

\begin{tabular}{lll}
\hline Company name & Description & Website \\
\hline KAZTECHNOINNOVATIONS & $\begin{array}{l}\text { Small machine shop of composite } \\
\text { manufacturing parts up to } 6 \mathrm{~m} \text { in length }\end{array}$ & http://www.kti.kz/ \\
\hline VASTE & $\begin{array}{l}\text { Manufacturing of glass fiber composites, } \\
\text { the largest wholesaler of carbon fiber } \\
\text { materials in Kazakhstan }\end{array}$ & https://vaste.satu.kz. \\
\hline MOST\&K & $\begin{array}{l}\text { A young company specializing in the retail } \\
\text { of carbon fiber products, including } \\
\text { chopped and milled fiber }\end{array}$ & $\mathrm{https://mostandk.kz/}$ \\
\hline Industrial.kz & Retailer of carbon fiber films & $\mathrm{https://industrial.kz}$ \\
\hline BVBAlyans & Retailer of carbon fiber tubes & $\mathrm{https://bvbalyans.kz/}$ \\
\hline Specmet.kz & Retailer of carbon fiber films & $\mathrm{https://Specmet.kz}$ \\
\hline
\end{tabular}

\subsection{China}

China is reported to have one of the largest carbon fiber and composite materials manufacturing setup. However, the country does not have legislative regulations or requirements for recycling CFRP waste. The EOL products are discharged mainly to landfills. However, currently, several research works are carried out to investigate the implementation of more cost-effective and efficient ways of CFRP recycling. For example, some authors propose using CFRP in the production of eco-efficient cementbased materials [12], and others study microwave thermolysis claiming to be more efficient compared to conventional thermolysis [21].

The main sectors where CFRP is predominantly used are commercial airplanes and wind turbine blade manufacturing. Akbar and Liew [12] have estimated the potential CFRP waste amounts in both sectors in China. Assuming 25 years lifespan, they 
estimated that around 22 and 75 thousand tons of waste from commercial aircraft and wind blades disposal respectively will be accumulated in landfills by 2044 if no recycling activities are undertaken [12]. Moreover, the Chinese wind power industry started developing rapidly from 2010 onwards, therefore, a substantial amount of waste is projected to be disposed from the year 2035 and will increase sharply exceeding the CFRP waste from the aeronautical sector [12].

CFRP material is used in different applications and subject to different operating conditions while in service. However, composite materials are designed to withstand high loads and complex fatigue for decades. For example, composite blades of wind turbines remain resistant to loads even after service time $(20-25$ years) [22]. China remains one of the leaders in the onshore wind industry and the number of composite material used in the wind energy sector is only increasing. In 2019, a record wind energy capacity was installed, and the total energy generation capacity reached almost $30 \mathrm{GW}$ [23]. According to Liu and Barlow [24], 40\% of the global blade waste will come from China (Figure 3), reaching several thousands of tons that need to be processed as early as possible. The immense future flows of potential CFRP waste from the aeronautical and wind turbine sectors can not be underestimated and necessary actions should be taken to address the issue.

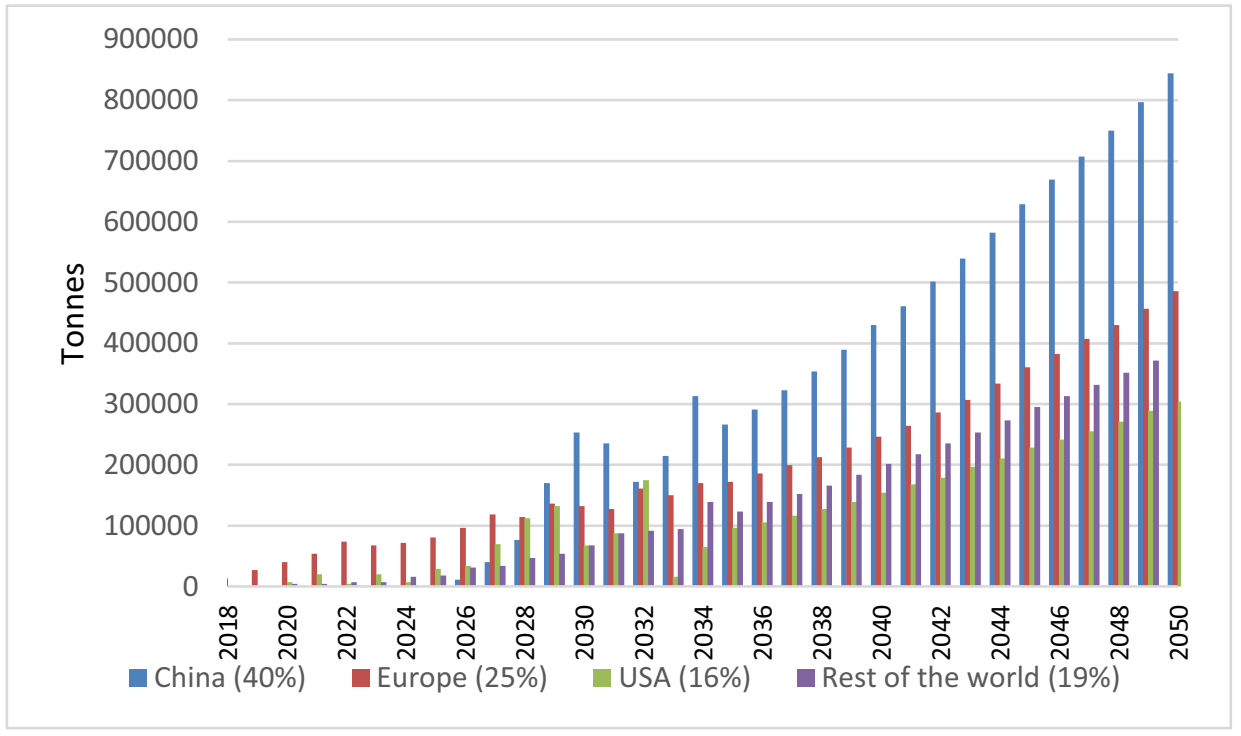

Figure 3. Potential wind turbine blade waste from 2018 to 2050 [24]

\subsection{Russia}

Russian waste management system is not well developed, with about $90 \%$ of waste going to landfills, and with no well-established culture of recycling, waste separation, and incineration [25]. The capacity of existing landfills is reaching its limit and they are extremely dangerous for the environment as toxic gases are released. However, the public and government raised a concern related to the growing number of landfills and waste management issues. Therefore, in 2018, the new national project named "Ecology" was initiated to protect the environment according to which all unauthorized landfills should 
be liquidated by 2024 . These steps towards waste management are expected to eventually lead to the need for CFRP waste management too. At present, Russia does not only utilizes products made from CFRP but also produces them. "UMATEX group", for example, which is a part of the state corporation "Rosatom", produces carbon fiber composites used in construction, shipbuilding, automotive, and other industries. Key customers of their products are local wind turbine blades and aircraft manufacturers [26].

The ZUKM plant, a division of mentioned "UMATEX group", is testing new fiber cutting equipment that is envisaged to solve the problem with carbon fiber productionassociated waste. This composite recycling system will allow the production of new products for the key enterprises of the Russian industry [27].

As was expected by experts' estimation, the total volume of production of products from composite materials in Russia should have reached 120 thousand tons by 2020 . However, this represents an insignificant share of the global composite market, which is dominated by China (28\%), the United States (22\%), the EU (14\%) [28].

The Russian wind turbine energy industry is not at a comparable level as the Chinese, but the potential growth of this sector is inevitable. According to Russian legislation, the goal in the wind energy sector is to reach $3.35 \mathrm{GW}$ of power generation by 2024 and 4.5 GW by 2030 [29]. Assuming that to generate $1 \mathrm{~kW}$ power $10 \mathrm{~kg}$ of material $(6 \%$ of which is CFRP) is used, the potential waste from wind turbine blade manufacturing is estimated to be 2.7 kilotons. As a result, Russia is expected to face the problem with composite materials related waste later and on a lesser scale due to the immaturity of the industry.

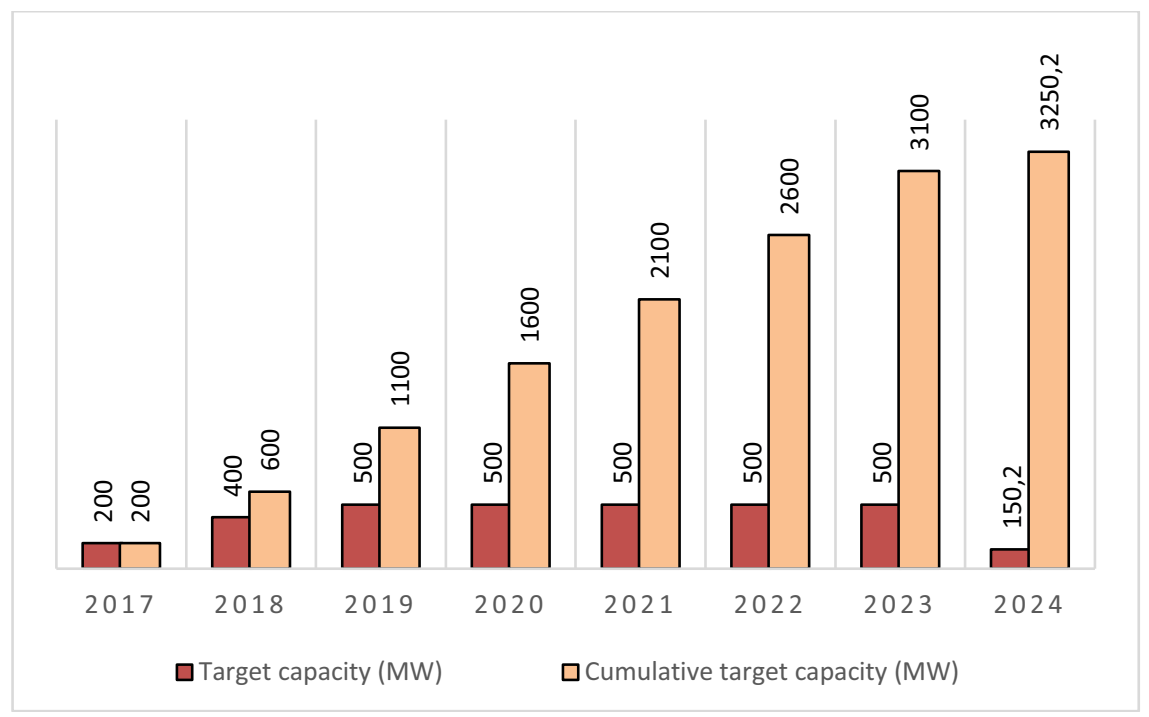

Figure 4. The Russian goal for installed wind power by 2024 [29].

In addition to the wind energy sector, Russian manufacturers use CFRP in the production of military and commercial aircraft. Until present, outdated aircraft are left at aircraft scrapyards after they are disposed which includes dismantling of the remaining important components [30]. The current disposal procedures would not be viable in the future as air transport building materials are replaced by others. Composite materials are now used instead of precious metals. Therefore, the correct disposal method would protect the environment, save lands from dumping waste, and bring benefits to the economy of the country [28]. 
The leading manufacturing enterprise in Russia, the "Tekhnologiya", produces up to 15 tons of components made of polymer composite materials (PCM) per year. These include components used for the tail of the promising domestic airliner MS-21, soundabsorbing structures for SAM-146, and PD-14 aircraft engines. A share of composite materials in manufacturing MS-21 and other Russian aircraft is up to $35 \%$ of the weight, while in previous generation aircrafts this segment was less than $10 \%$ [31].

The Russian government started considering composite materials as a viable material type since 2013 and, as a result, there is a steady growth in the production and consumption of various types of CFRPs [32]. Moreover, various standards and codes were introduced to ease and increase its application range [32]. Large manufacturers of carbon fiber composites (based on multilayer, single-layer nanotubes) are "Moscow Center for Nanotechnology", "Novosibirsk OCSiAl" and "Tambov Nanotechcenter LLC". There are also about 30-50 large manufacturers of composite materials and associated products in St. Petersburg and about 20-30 distributors of products and materials from other regions and countries [31].

\section{Recommendations on CFRP recycling in Kazakhstan}

Despite the numerous research efforts around carbon fiber waste recycling technologies, the recycling of CFRP has not been established in Kazakhstan. Nevertheless, the continuous increase of the wind turbine sector's output in the next three decades will generate thousands of tons of CFRP waste and will be sent to landfills or incinerated if not recycled. The utilization of CFRP in different sectors is becoming more popular, which will also eventually become a challenge and will need to be addressed. Hence, Kazakhstan needs to consider and integrate various recycling techniques, such as, for example, mechanical and thermal recycling. These techniques are known as the most tolerant and universal to different waste types and do not involve contaminants during chemical processes. Mechanically recycled products can be used as fillers for cement constructions, whereas pyrolysis might result in recycled fibers production which can further be reused in different non-structured elements. The potential waste from neighboring countries in substantial amounts which were described in the section above can also be beneficial as the supply chain of carbon fiber recycling is largely dependent on transportation distances. However, there are certain challenges regarding the transportation of CFRP waste. First of all, the products require initial size reduction before transportation which will have additional costs [33]. Secondly, distances from the source of waste to potential recycling site should be considered as they could impact the viability of the process. According to Li et al. [34], transportation costs constituted less than $1 \%$ of total costs for mechanical recycling of CFRP waste with $200 \mathrm{~km}$ of theoretical distance. Considering mechanical recycling is one of the cheapest methods of CFRP processing[35], transportation between neighboring countries should be justifiable, though optimization of routes and potential site location is a subject of further research. Manufacturers will need to commence centralized collections in their countries in order to boost economies of scale and minimize transportation costs and its environmental impact. Taking into account that Kazakhstan is located between two large countries, Kazakhstan might become a pioneer of more proactive recycling of composite materials. This can be done if necessary actions are taken at present including creating a scientific groundwork, developing commercially viable approaches, and eventually building recycling plants. Incorporating social concerns about CFRP waste in the region, 
economic viability, and the development of engineering solutions for recycling require a transdisciplinary approach. Further research could be the study on the viability of recycling in the region taking into account transportation, and comprehensive investigation of possible applications in a local context. Also, the findings of this work can be compared with the other countries and generalized in future.

\section{Conclusion}

This paper described and analyzed the current status of CFRP application and recycling in Kazakhstan and its neighboring countries such as Russia and China. The work analyzed the amount of CFRP waste from different industries including wind turbines and aeronautical sectors, including the current supply and balance sheet of CFRP products. It is found that the carbon fiber market of retail products is incomparably small in Kazakhstan. Nevertheless, the potential waste from the wind turbine manufacturing industry generated due to the plans of the government to increase wind turbine power may create certain challenges in the future. China and Russia will face significantly larger waste outputs from the end-of-life wind turbines and aircraft. This will ultimately develop a considerable CFRP waste capacity. All of these conditions might merge into an opportunity for Kazakhstan as a center for recycling CFRP waste in the region.

\section{Acknowledgments}

The authors would like to thank Nazarbayev University for funding this article under the Faculty Development Competitive Research Grant Program (FCDRGP) Grant No. 110119 FD4524.

\section{References}

[1] S. R. Naqvi, H. M. Prabhakara, E. A. Bramer, W. Dierkes, R. Akkerman, and G. Brem, A critical review on recycling of end-of-life carbon fibre/glass fibre reinforced composites waste using pyrolysis towards a circular economy, Resour. Conserv. Recycl., vol. 136, pp. 118-129, Sep. 2018.

[2] J. Wellekötter, J. Resch, S. Baz, G. T. Gresser, and C. Bonten, Insights into the Processing of Recycled Carbon Fibers via Injection Molding Compounding, J. Compos. Sci., vol. 4, no. 4, p. 161, Oct. 2020.

[3] Markets and Markets, CF \& CFRP Market by Source (Virgin, Recycled), Precursor (PAN, Pitch, Rayon), Resin (Thermosetting, Thermoplastic), Manufacturing Process, End-use Industry, and Region - Global Forecast to 2025, 2020.

[4] J. Zhang, V. S. Chevali, H. Wang, and C. Wang, Current status of carbon fibre and carbon fibre composites recycling, Compos. Part B, vol. 193, no. December 2019, p. 108053, 2020.

[5] A. K. Bledzki, H. Seidlitz, K. Goracy, M. Urbaniak, and J. J. Rösch, Recycling of Carbon Fiber Reinforced Composite Polymers-Review_-Part 1: Volume of Production, Recycling Technologies, Legislative Aspects, Polymers (Basel)., vol. 13, no. 2, p. 300, Jan. 2021.

[6] F. Meng, E. A. Olivetti, Y. Zhao, J. C. Chang, S. J. Pickering, and J. McKechnie, Comparing Life Cycle Energy and Global Warming Potential of Carbon Fiber Composite Recycling Technologies and Waste Management Options, ACS Sustain. Chem. Eng., vol. 6, no. 8, pp. 9854-9865, Aug. 2018.

[7] Carbon Conversions, 2021, Facility. Accessed: 10.01.2021. [Online]. Available: https://carbonconversions.com/facility/.

[8] CFK, 2010, CFK Valley Stade Recycling GmbH \& Co KG. Accessed: 15.01.2021. [Online]. Available: https://www.cfk-recycling.de/index.php?id=57. 
[9] ELG, 2018, ELG Carbon Fibre accelerates UK expansion plans. Accessed: 15.01.2021. [Online]. Available: https://www.elgcf.com/news/elg-carbon-fibre-accelerates-uk-expansion-plans.

[10] Karborek, 2021, Company. Accessed: 15.01.2021. [Online]. Available: http://www.karborekrcf.it/

[11] I. Delvere, M. Iltina, M. Shanbayev, A. Abildayeva, S. Kuzhamberdieva, and D. Blumberga, Evaluation of Polymer Matrix Composite Waste Recycling Methods, Environ. Clim. Technol., vol. 23 , no. 1, pp. 168-187, Jan. 2019.

[12] A. Akbar and K. M. Liew, Assessing recycling potential of carbon fiber reinforced plastic waste in production of eco-efficient cement-based materials, J. Clean. Prod., vol. 274, p. 123001, Nov. 2020.

[13] IDFRK, 2021, Leasing Of Air Transport. Accessed: 15.01.2021. [Online]. Available: https://idfrk.kz/en/leasing/air-transport/.

[14] M. Baigarin, 2020, План 2020 года по производству электроэнергии из возобновляемых источников выполнен. Accessed: 15.01.2021. [Online]. Available: https://lenta.inform.kz/ru/plan2020-goda-po-proizvodstvu-elektroenergii-iz-vozobnovlyaemyh-istochnikov-vypolnen-nurlannogaev a3722534.

[15] A. Vidyanova, 2020, Ветряные станиии генерируют 45\% электроэнергии ВИЭ. Accessed: 20.01.2021 [Online].. Available: https://kapital.kz/economic/87654/vetryanyye-stantsii-generiruyut45-elektroenergii-vie.html.

[16] Kursiv.kz, 2020, Казахстан в 2020 году отобрал 16 проектов ВИЭ на 148 мегаватт. Accessed: 25.01.2021. [Online]. Available: https://kursiv.kz/news/otraslevye-temy/2020-12/kazakhstan-v2020-godu-otobral-16-proektov-vie-na-148-megavatt.

[17] Bureau of National statistics, 2021, Carbon fibers and products of them: TNVED 6815101000. Accessed: 20.01.2021. [Online]. Available: https://stat.gov.kz/official/industry/11/statistic/6.

[18] T. P. Sathishkumar, S. Satheeshkumar, and J. Naveen, Glass fiber-reinforced polymer composites A review, J. Reinf. Plast. Compos., vol. 33, no. 13, pp. 1258-1275, 2014.

[19] KAZTECHNOINNOVATIONS, 2021, What Can We Do?. Accessed: 25.01.2021 [Online]. Available: http://www.kti.kz/service/proizvodstvo-izdelij-iz-kompozitnyh-materialov.

[20] MOST\&K, 2021, MOST\&K: About the company, 2021. Accessed: 25.01.2021 [Online]. Available: https://mostandk.kz/info-about.

[21] J. Deng et al., Recycling of Carbon Fibers from CFRP Waste by Microwave Thermolysis, Processes, vol. 7, no. 4, p. 207, Apr. 2019.

[22] L. Mishnaevsky, Sustainable End-of-Life Management of Wind Turbine Blades: Overview of Current and Coming Solutions, Materials (Basel)., vol. 14, no. 5, p. 1124, Feb. 2021.

[23] GWEK, 2019, “Global Wind Report 2019,". Accessed: 28.01.2021 [Online]. Available: https://gwec.net/wp-content/uploads/2020/08/Annual-Wind-Report_2019_digital_final_2r.pdf.

[24] P. Liu and C. Y. Barlow, Wind turbine blade waste in 2050, Waste Manag., vol. 62, pp. 229-240, Apr. 2017.

[25] IFC, 2014, Waste In Russia: Garbage Or Valuable Resource?. Accessed: 25.01 .2021 [Online]. Available: http://documents1.worldbank.org/curated/pt/702251549554831489/pdf/Waste-inRussia-Garbage-or-Valuable-Resource.pdf.

[26] UMATEX, 2021, Applications. Accessed: 25.01.2021 [Online]. Available: https://en.umatex.com/.

[27] Rosatom, 2021, Promising Materials and Technologies, Accessed: 25.01.2021 [Online]. Available: https://rosatom.ru/en/rosatom-group/new-business-areas/other-products/.

[28] A. V. Petrov, M. S. Doriomedov, and S. Y. Skripachev, Recycling Technologies Of Polymer Composite Materials (Review), Proc. VIAM, no. 8, pp. 9-9, 2015.

[29] G. Stefan and D. Roman, 2017 Perspectives of the wind energy market in Russia. Accessed: 10.02.2021 [Online]. Available: https://library.fes.de/pdf-files/bueros/moskau/13474.pdf.

[30] UtilVtorProm, 2016, Recycling and disposal of air transport. Accessed 20.02.2021. [Online]. Available: $\quad$ https://xn--80ancacol ch7azg.xn--j1amh/ru/utilizatsiya-othodov/utilizatsiyavozdushnogo-transporta/.

[31] E. Isayeva, 2015, Промышленные композиторы, Коммерсантъ. Accessed 20.02.2021. [Online]. Available: https://www.kommersant.ru/doc/2825099.

[32] P. Sidorenko and I. Karpes'o, 2018, Disposal of composites: problems and promising solutions, Basalt.Today. Accessed 22.02.2021. [Online]. Available: https://basalt.today/ru/2018/05/15941/.

[33] S. Halliwell, End of Life Options for Composite Waste, Natl. Compos. Network. Best Pract. Guid., 2006.

[34] X. Li, R. Bai, and J. Mckechnie, Environmental and fi nancial performance of mechanical recycling of carbon fi bre reinforced polymers and comparison with conventional disposal routes, J. Clean. Prod., vol. 127, no. 2016, pp. 451-460, 2016.

[35] P. A. Vo Dong, C. Azzaro-pantel, and A. Cadene, Resources, Conservation \& Recycling Economic and environmental assessment of recovery and disposal pathways for CFRP waste management, Resour. Conserv. Recycl., vol. 133, no. August 2017, pp. 63-75, 2018. 